\title{
Debate
}

\section{The Historical Changes and Continuities of Swiss Parliamentary Recruitment}

\author{
Andrea Pilotti \\ University of Lausanne
}

National ruling elites have long been a subject of scholarly research. Starting in the late $19^{\text {th }}$ century, the advent of representative democracy led many scholars to ask who the ruling classes are, to what extent they constitute a separate class, and whether they are "unified" or, rather, "pluralistic" (Hubé 2009: 336). In this particular area of research, Switzerland lags significantly behind other Western countries such as Germany, France, England, or the United States.

In my own research on Swiss parliamentary recruitment (Pilotti 2012), I have chosen an approach that relies on two dimensions: the process of democratization and the process of professionalization (Best and Cotta 2000). Borchert (2008: 273) stresses that these two processes are interrelated: "professionalization [is] both a result of democratization and a prerequisite for its further extension into the parliamentary sphere. The battle over legislative compensation [is] basically one about democracy and the social opening of the political sphere." The first process helps us analyze how the degree of inclusiveness of parliamentary recruitment of various social groups (age, sex, social origin, training, profession) has evolved over time. As for the second dimension, it helps us reflect on the way in which, on the one hand, the office of Member of Parliament (MP) has become a true remunerated profession, and on how, on the other hand, it is increasingly viewed as distinct from other social ties. While it occurs at the same time as democratization, professionalization generates new forms of selectiveness. According to Cotta and Best (2000: 495), "while democratization refers to an opening of the channels for political participation and legislative recruitment to more social groups, professionalization refers to the process whereby those recruited tend to establish areaspecific standards and routines which increase their own control over legislative careers, income, legal status and social standing, thus restricting access to the parliamentary arena". Adopting this double perspective allowed me to address several questions: What are the defining features of the members of the Federal Assembly? Within a militia system, i.e. without professional MPs, which resources and qualities matter most? How do they change over time with regard to the changing balance of power between political parties and with regard to the transformations of the parliamentary institution in recent times?

To address these questions, it is necessary, on the one hand, to take into account the main institutional reforms that throughout the $20^{\text {th }}$ century might have affected the processes of democratization and professionalization, and, on the other hand, to assess whether and how the profile of Swiss MPs changed in connection with those reforms. 


\section{The change of electoral rules and its impact on the MPs' profile}

Following the first significant change in electoral rules, i.e. the introduction of proportional representation (PR) for elections to the National Council (finally accepted in 1918 after two failed popular votes in 1900 and 1910), we observe the entry of a number of social groups into the Swiss Parliament that had previously been excluded or severely underrepresented. Thus, this first constitutional change opened the doors of parliament to many socialist and agrarian members, which led, on the one hand, to a greater presence of MPs coming from a working-class background and the petite bourgeoisie, as well as a greater presence of trade unions officials and farmers, and, on the other hand, to a smaller number of lawyers, MPs with a university degree (even if they are still the majority), and military officers.

The ratio of elected representatives from working-class families increased after the introduction of PR: less than $10 \%$ before the constitutional change to about $15-17 \%$ after the reform and until the 1970s-1980s. Over the last two decades of the $20^{\text {th }}$ century the ratio was about $20 \%$, while in the 2000 s it increased to $25 \%$. $^{1}$ Regarding the main parliamentary groups, the Socialist Party (SP) has historically the largest ratio of MPs from the working class (often no less than 40\%), while the ratio is much lower for bourgeois groups (often no more than 10\%), i.e. the Radical Party (FDP), the Christian Democratic Party (CVP) and the Swiss People's Party (SVP) (Figure 1).

Since the 1930s and 440s, however, the profile of Swiss MPs has remained very stable if we consider the socio-professional composition of the Federal Assembly, a reflection of the great stability of the political balance in the composition of the legislative body. The stable profile of elected representatives can be explained by the preponderance of MPs with a university degree, MPs with a military rank, members of boards of directors, and MPs with a strong local political background. From a professional point of view, the profile inherited from the $19^{\text {th }}$ century remained unchanged for the greater part of the $20^{\text {th }}$ century, with a predominance of independent professions (lawyers, entrepreneurs, and farmers) and a weak presence of public employees (Table 1). Therefore, the militia system has mitigated the impact of the introduction of PR on the descriptive representation of professional groups. ${ }^{2}$

After a long period of inertia, women were elected to Parliament for the first time at the beginning of the 1970s, after the introduction of the women's vote at the federal level in 1971. This was only the second biggest institutional reform to occur in Switzerland in the $20^{\text {th }}$ century. With the entry of women into the Swiss Parliament, even though they remain underrepresented, the descriptive representation of people under 50, those who do not hold a military rank, or those who are not members of boards of directors and also the people from the working class becomes more important. ${ }^{3}$ The last decades of the $20^{\text {th }}$ century are marked not only by the introduction of women's suffrage, but also by debates on parliamentary professionalization, an issue that was entirely new for Switzerland.

\footnotetext{
${ }^{1}$ However, even if more MPs are from the working class, their voting decisions in final votes are not necessarily affected by their socioeconomic backgrounds, but rather by party affiliation (Lloren, Rosset and Wüest, this debate).

${ }^{2}$ For example, before being elected to parliament, many socialist MPs are somehow "forced" to change their first professional activity as blue-collar workers or public employees. In order to facilitate their entry into the Federal Assembly, they become trade unions officials or members of local or regional governments. Indeed, these professions, unlike those of industry workers, are better adapted to the militia system, because they are more complementary to the non-professional parliamentary office. Therefore, this explains why the ratio of blue-collar workers who serve as MPs is historically very low in the Swiss Parliament (less than $1 \%$ ).

${ }^{3}$ Between the 1970s-1980s and 2000s the ratio of parliamentarians coming from a working-class background is higher among women MPs (on average about 29\%) when compared to the men MPs (on average $22 \%$ ).
} 
Figure 1: Share of Swiss MPs from the working class at the Federal Assembly and by parliamentary groups (1910-2010), in \%

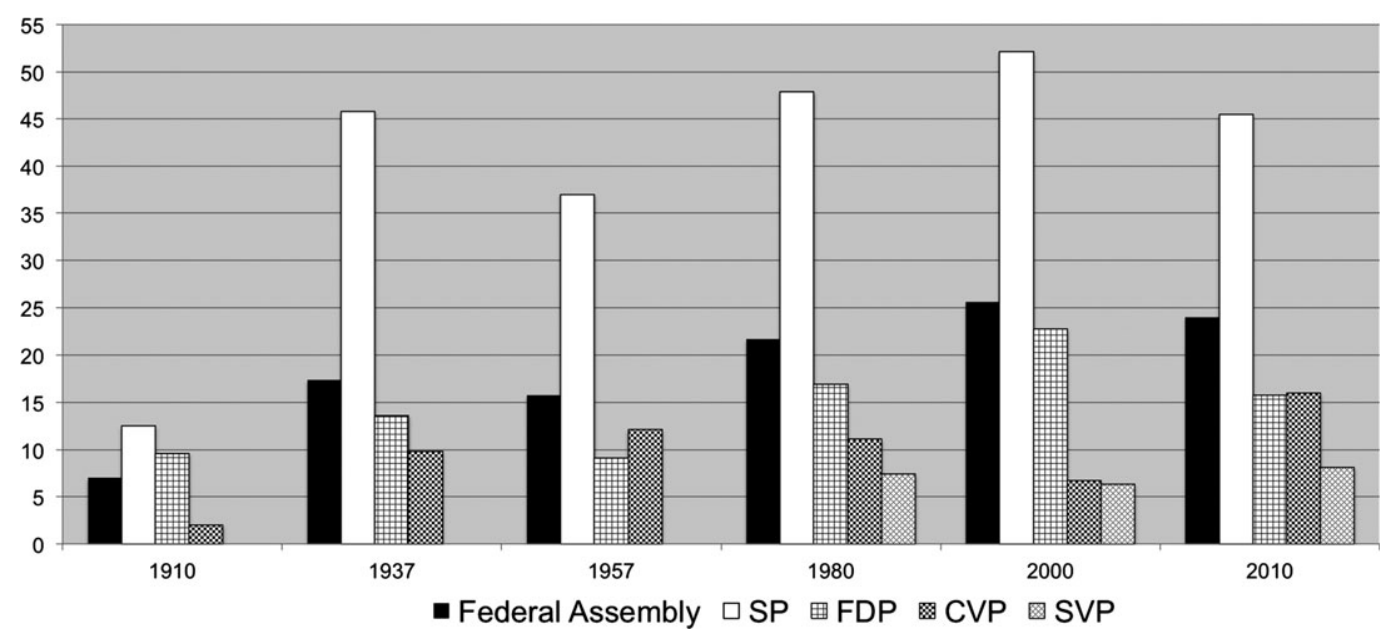

Source: Swiss Elite Database, University of Lausanne.

Table 1: The presence of some professional groups at the Federal Assembly (1910-2010), in \% (N)

\begin{tabular}{|c|c|c|c|c|c|c|}
\hline & 1910 & 1937 & 1957 & 1980 & 2000 & 2010 \\
\hline Lawyers & $26.4(57)$ & $21.3(51)$ & $14.0(34)$ & $21.4(53)$ & $22.1(55)$ & $13.6(34)$ \\
\hline Entrepreneurs & $10.6(23)$ & $8.8(21)$ & $11.1(27)$ & $6.5(16)$ & $14.5(36)$ & $14.4(36)$ \\
\hline Farmers & $6.0(13)$ & $11.3(27)$ & $13.6(33)$ & $8.1(20)$ & $10.0(25)$ & $8.8(22)$ \\
\hline Public Employees & $6.9(15)$ & $5.0(12)$ & $4.9(12)$ & $16.9(42)$ & $9.6(24)$ & $8.8(22)$ \\
\hline
\end{tabular}

Source: Swiss Elite Database, University of Lausanne.

\section{Parliamentary professionalization in Switzerland: a late, contested, and unfinished process}

In Switzerland, the compensation of MPs - which is key to the professionalization of parliamentary office-remained purely symbolic for a very long time, due to the importance of the militia principle. According to this principle, the responsibilities of elected representatives are conceived as a service to the community, performed in an honorary capacity, and thus as not warranting the payment of a genuine compensation. For the first time in the 1970s, there was an awareness of the limitations of the militia system with regard to parliament's lack of representativeness when compared to the rest of the population. However, there clearly was a lack of political will to implement a profound reform of Parliament until the 1980s.

The 1990s became a turning point with the discussion of a new project of parliamentary reform that came after two scandals that profoundly changed the face of Swiss politics at the end of the 1980s: the Kopp scandal and the Secret Files scandal. For the first time, a majority of elected representatives appeared to have the political will to reform and professionalize the Federal Assembly in order to enhance their work conditions, and thus, better fulfill their duties (Pilotti 2012). 
Parliamentary professionalization in Switzerland not only lags behind and is unfinished when compared to other Western countries, but also remains contested by a segment of the economic right and by the nationalist right (i.e., the SVP). The economic right's argument is mainly financial, linked to the view that the cost of the reform is excessive, and is connected to the fear of seeing the state assume a tighter grasp on society and on the economy. The nationalist right puts forward identity-based arguments: they seek to preserve the militia system and denounce the parliamentary professionalization process, which they view as an attempt to change the nature of the system and to call into question the "Swiss exception".

Although the opposition was successful in blocking the two main components of the 1991 reform through popular vote (an increase in the compensation of MPs and the possibility for them to hire a personal assistant), the Parliament has adopted a number of measures that have helped strengthen its role and competences since the mid-1990s.

Parliamentary reforms seeking to further professionalize the activities of federal elected representatives led, on the one hand, to the advent of genuine professional MPs who could make a living through holding public office, and, on the other hand, to an increased number of MPs who had a complementary job in addition to their political office. The parliamentary reforms had also some implications for the descriptive representation of the working class. Indeed, before those reforms (until the early 1960s), the ratio of MPs coming from a working-class background was on average about $13 \%$, while from the 1970s-1980s until the 2000s, that is the period marked by an increased compensation, the share is on average about $23 \%$. The latter evolution seems therefore to show that the professionalization does not necessarily restrict access to the electoral mandate, at least in terms of descriptive representation of the working class.

Overall, the professionalization of parliamentary office did not affect all MPs in the same way. It followed the left-right political cleavage as well as the gender cleavage. Indeed, professionalization is more pronounced among socialist MPs, who have fewer external resources in addition to their public office, contrary to MPs from bourgeois parties, who can often count on additional financial resources linked, for instance, to their participation in multiple boards of directors (Figure 2). The professionalization is also clearly more advanced among female MPs (Figure 3). This difference can be explained by the fact that most women who are members of Parliament have fewer connections to economic circles than their male counterparts, who sometimes derive significant income from these ties. Another change also connected in part to the increased professionalization of Swiss MPs has to do with a decline in the practice of holding multiple offices (political, economic, and on extra-parliamentary commissions), a phenomenon that highlights some perceived differences between parliamentary activities and other social spheres.

\section{The Swiss Parliament as an always "distorting" mirror of society}

In addition to the growing number of women and the development of a professionalization process, parliamentary recruitment in Switzerland in the last 30 years has also featured a transformation, especially since the second half of the 1990s, of the balance of power between the main political parties, with notable progress on the part of the SVP and a decline of the FDP and CVP. This last event can help us better understand some of the changes in the sociological profile of Swiss MPs, such as, for instance, the decreasing number of MPs with academic training and the increasing number of entrepreneurs, at a time when the number of lawyers and military officers (which can be linked to the greater presence of women) decreased. 
Figure 2: Share of Professional MPs at the Federal Assembly and by parliamentary groups (19802010), in \%

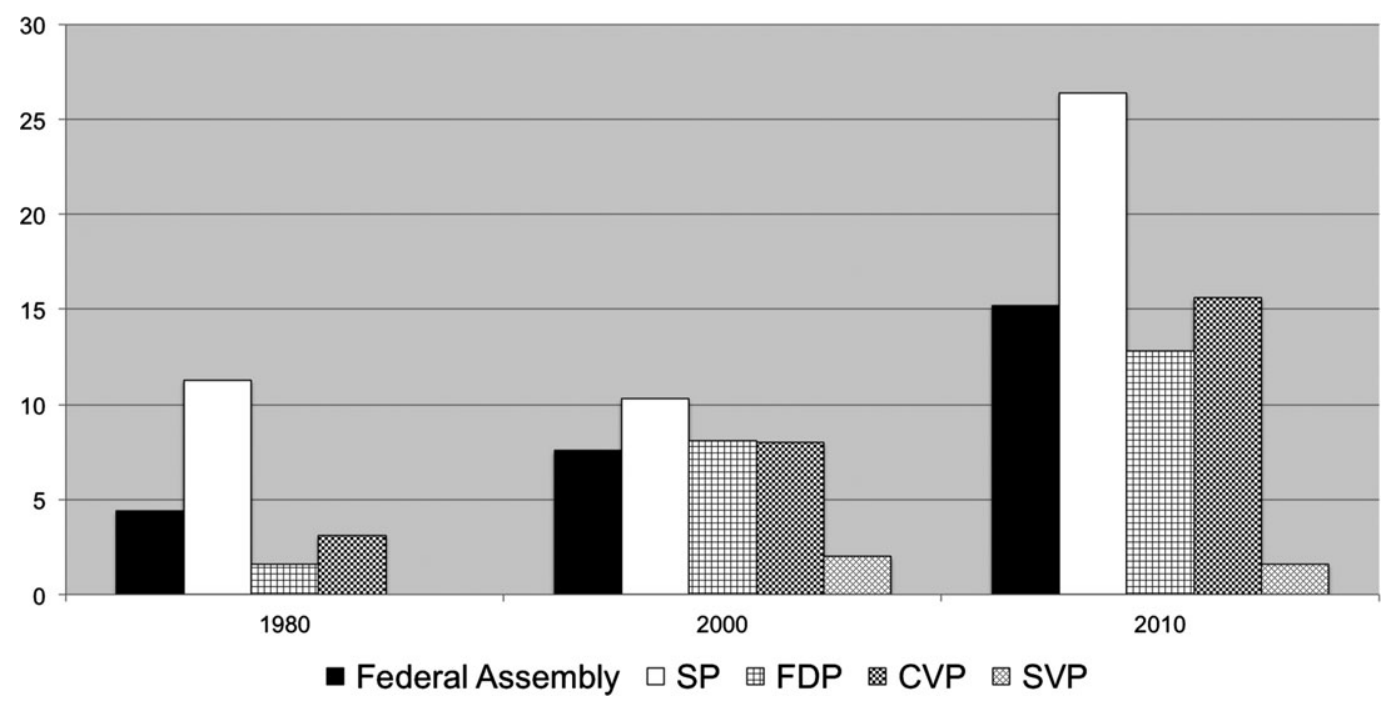

Source: Swiss Elite Database, University of Lausanne.

Figure 3: Share of Professional MPs at the Federal Assembly and by sex (1980-2010), in \%

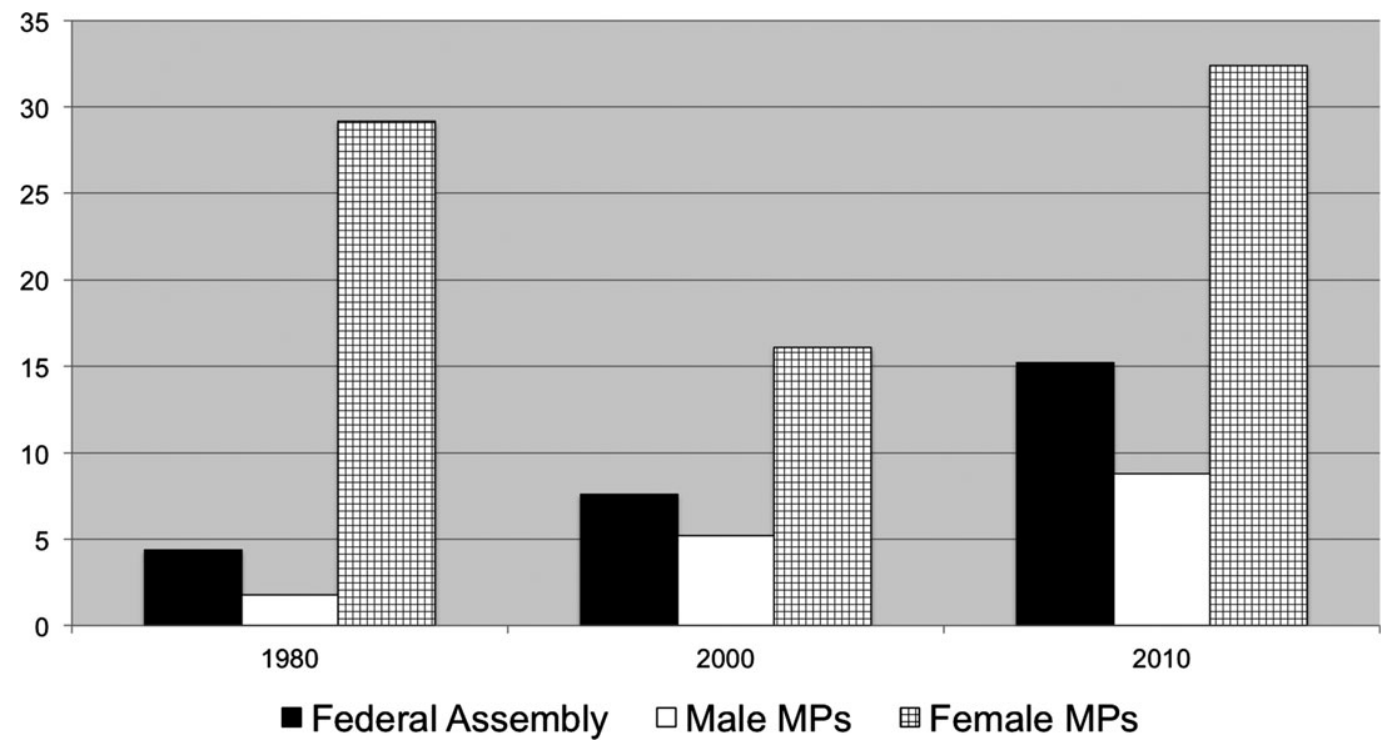

Source: Swiss Elite Database, University of Lausanne. 
Overall, despite the two changes in Swiss electoral rules described above and improvement in the material conditions of MPs that resulted from the process of professionalization, the degree of inclusiveness of parliamentary recruitment in Switzerland remains rather limited. It appears clearly that, historically, the militia system and the modest professionalization of the Swiss Parliament have benefited the most well-off in society. ${ }^{4}$ Thus, in the words of Kerr (1981: 35), the Federal Parliament is still a "distorting mirror" of Swiss society, since the possession of certain resources is still an important requirement to become a member of the Swiss Parliament (male, military career, over 50, academic training, independent professions, members of boards of directors). When compared to the Swiss population as a whole, those who possess those resources are overrepresented at the expense of other social and professional profiles (women, people under 40-45, not academically trained, wage earners) (see also Falcon and Pilotti 2013).

\section{Regarding some specific features of partisanship}

My research also confirmed that the importance of certain resources varied according to the partisan affiliation of elected representatives. Among the four main parliamentary groups, one finds that deputies are representative of the overall Swiss population to varying degrees.

MPs from the Radical and the Christian Democratic parties always include a great number of MPs with a university degree and military officers. From a professional point of view, the FDP members of Parliament have a ratio of lawyers and entrepreneurs greater than the average in the Federal Assembly as a whole, while the Christian Democratic group is "dominated" by lawyers, and-more recently-entrepreneurs and independent consultants. Radical Party MPs have stronger ties to the economy as executives in the boards of the largest Swiss companies and private limited companies. Among CVP members of Parliament instead one finds an important ratio of corporate executives in local and regional companies, a phenomenon that offsets the more tenuous ties of the party with the great industrial groups and banks.

The SVP group recruits its members most widely among army officers and very little among women. The formerly agrarian parliamentary group has undergone an important transformation of the educational background of its members, since in recent years academic training has become a less and less important resource. This change occurred in parallel with the increased electoral success of the SVP with workers and low-skilled workers (Gottraux and Péchu 2011). The professional profile of SVP members of Parliament, with a decreasing but still important presence of farmers and an increased presence of entrepreneurs in the 2000s, clearly reflects the new ideological orientation of the party, which is focused on the interests of farmers but also those of small and medium-sized businesses.

Finally, the SP parliamentary group is decidedly more open to women and to under 50 . The resources that come with a military career and the holding of seats on boards of directors have only a marginal, even insignificant, importance. This defect, however, is counterbalanced by a more substantial local political background. Regarding training, the profile of socialist MPs underwent profound changes starting in the 1980s, when-for the

\footnotetext{
${ }^{4}$ However, this does not mean that a high degree of parliamentary professionalization reduces the economic or social gap between MPs and citizens. Indeed, this gap is also strong in the US Congress, despite its high degree of professionalization (Carnes, this debate).
} 
first time - the parliamentary group comprised a majority of MPs with a university degree. This evolution also reflects the new orientation of socialist voters, many of whom have a graduate education and belong to the new upper middle classes (Hirter 2000; Oesch and Rennwald 2010). On a professional level, the SP parliamentary group has historically featured an important proportion of trade unions officials, although in the 2000s independent consultants and professional MPs became more numerous. The presence of public employees is also more significant in that parliamentary group than in any other.

\section{The Swiss case within a comparative perspective}

Overall, in addition to a low degree of parliamentary professionalization (Z'graggen 2009), Switzerland features at least five other specific characteristics in comparison to other European countries in the course of the $20^{\text {th }}$ century. First, it is among the last countries to grant the right to vote and run for office to women at the national level (1971), which explains why women were only elected late to the Federal Parliament. Their presence, however, grew noticeably, although it remained inferior to the proportions seen in other parliaments, for example the ones in Germany, the Netherlands, or Scandinavian countries (Christmas-Best and Kjaer 2007). Second, academic training, while still a resource that most members of the Swiss Parliament possess, has only decreased in importance in recent years, while the proportion of MPs with a university degree has kept growing in all European legislative assemblies (Gaxie and Godmer 2007). Third, because of the militia principle, the Swiss Parliament is also characterized by a professional profile rather different from that found in most legislative assemblies in Europe. Among Swiss deputies, the proportion of lawyers, entrepreneurs, and farmers is clearly higher than the average numbers found in other parliaments. The presence of public employees instead remains low, while it is predominant in other European countries (Cotta and Tavares de Almeida 2007). Fourth, federal elected representatives often have significant local political backgrounds, which come, finally, with a parliamentary longevity unrivaled in an international comparative perspective.

\section{References}

Best, H. and M. Cotta (eds.) (2000). Parliamentary Representatives in Europe 1848-2000. Legislative Recruitment and Careers in Eleven European Countries. Oxford: Oxford University Press.

Borchert, J. (2008). Political Professionalism and Representative Democracy Common History, Irresolvable Linkage and Inherent Tensions. In Palonen, K., T. Pulkkinen and J. M. Rosales (eds.), The Ashgate Research Companion to the Politics of Democratization in Europe. Concepts and Histories. Surrey: Ashgate (267-283).

Christmas-Best, V. and U. Kjaer (2007). Why So Few and Why So Slow? Women as Parliamentary Representatives in Europe from a Longitudinal Perspective. In Cotta, M. and H. Best (eds.), Democratic Representation in Europe. Diversity, Change, and Convergence. Oxford: Oxford University Press (77-105).

Cotta, M. and H. Best (2000). Between Professionalization and Democratization: A Synoptic View on the Making of the European Representative. In Best, H. and M. Cotta (eds.), Parliamentary Representatives in Europe 1848-2000. Legislative Recruitment and Careers in Eleven European Countries. Oxford: Oxford University Press (493-526).

Cotta, M. and P. Tavares de Almeida (2007). From Servants of the State to Elected Representatives: Public Sector Background among Members of Parliament. In Cotta, M. and H. Best (eds.), 
Democratic Representation in Europe. Diversity, Change, and Convergence. Oxford: Oxford University Press (51-76).

Falcon, J. and A. Pilotti (2013). Do they represent us and do they worth representing us? A comparison of the evolution of the profile of Swiss MPs with the Swiss population. Paper presented at the ECSR Conference, Tilburg University, October 14-16, 2013.

Gaxie, D. and L. Godmer (2007). Cultural Capital and Political Selection: Educational Backgrounds of Parliamentarians. In Cotta, M. and H. Best (eds.), Democratic Representation in Europe. Diversity, Change, and Convergence. Oxford: Oxford University Press (106-135).

Gottraux, P. and C. Péchu (2011). Militants de l'UDC. La diversité sociale et politique des engagés. Lausanne: Antipodes.

Hirter, H. (2000). Wahlen 1999 - Zusammensetzung und politische Orientierung der Wählerschaft bei den eidgenössischen Wahlen. Bern: Haupt.

Hubé, N. (2009). Le recrutement social des professionnels de la politique. In Cohen, A., B. Lacroix and P. Riutort (eds.), Nouveau manuel de science politique. Paris: La Découverte (335-357).

Kerr, H. (1981). Parlement et société en Suisse. Saint-Saphorin: Editions Georgi.

Oesch, D. and L. Rennwald (2010). La disparition du vote ouvrier? Le vote de classe et les partis de gauche en Suisse. In Nicolet, S. and P. Sciarini (eds.), Le destin électoral de la gauche. Le vote socialiste et vert en Suisse. Genève: Georg, Genève (219-256).

Pilotti, A. (2012). Les parlementaires suisses entre démocratisation et professionnalisation (1910-2010). Biographie collective des élus fédéraux et réformes du Parlement helvétique. PhD Thesis, Faculty of Social and Political Sciences, University of Lausanne.

Z'graggen, H. (2009). Die Professionalisierung von Parlamenten im historischen und internationalen Vergleich. Bern: Haupt.

Andrea Pilotti is a researcher at the Institute of Political, Historical and International Studies, University of Lausanne, Switzerland. His current research interests include parliamentary recruitment as well as urban and regional politics. He is currently preparing a book based on his $\mathrm{PhD}$ thesis on Swiss parliamentary recruitment and the reforms of the Federal Assembly. He is an associated member of the Swiss Elite Project at the University of Lausanne (http://wp.unil.ch/eliteresearch). Address for correspondence: Institute of Political, Historical and International Studies (IEPHI), Géopolis Building, University of Lausanne, 1015 Lausanne, Switzerland; E-mail: andrea.pilotti@unil.ch 